\title{
The Role of Academic Self-Efficacy as a Mediator Variable between Perceived Academic Climate and Academic Performance
}

\author{
Moustafa Abd-Elmotaleb ${ }^{1,2}$ \& Sudhir K. Saha ${ }^{1}$ \\ ${ }^{1}$ Faculty of Business Administration, Memorial University, Newfoundland, Canada \\ ${ }^{2}$ Department of Business Administration, Faculty of Commerce, Assiut University, Egypt \\ Correspondence: Moustafa Abd-Elmotaleb, Faculty of Business Administration, Memorial University, \\ Newfoundland, Canada. E-mail: mama38@mun.ca
}

Received: July 10, $2013 \quad$ Accepted: July 26, $2013 \quad$ Online Published: August 14, 2013

doi:10.5539/jel.v2n3p117 URL: http://dx.doi.org/10.5539/jel.v2n3p117

\begin{abstract}
This study examines the mediating influence of academic self-efficacy on the link between perceived academic climate and academic performance among university students. The participants in the study consist of 272 undergraduate students at the University of Assiut, Assiut, Egypt. A scale to measure perceived academic climate, was developed. To ensure this scale was both reliable and valid we used Crombach's alpha test. We relied on Landry's category "self-efficacy for academic achievement" from The College Student Self-Efficacy Scale (CSSES) to assess academic self-efficacy. Participants' GPAs were used as a measure of academic performance. Descriptive statistics, (Person Product Moment Correlation, T-test as well as simple and multiple regressions) were used to analyze the data. The results demonstrated that perceived academic climate and academic self-efficacy significantly correlated with students' academic performance. The mediating effect of academic self-efficacy on the relationship between perceived academic climate and students' academic performance was also established. It is worth mentioning that academic self-efficacy mediated the relationship between perceived academic climate and academic performance in the theoretical schools sample (full mediation), male and female samples (partial mediation). In contrast, it could not mediate this relationship in the practical schools sample. On the basis of the findings, it was recommended that academic self-efficacy should be enhanced using counseling strategies.
\end{abstract}

Keywords: academic climate, academic self-efficacy, performance, Egypt

\section{Introduction}

Since the late 1950s, observers of educational and business organizations have garnered a rich array of research data from the study of organizational climate (Smith, 2002). Originally, "climate was used as a general notion to express the enduring quality of organizational life" (Hoy and Sabo, 1998). Organizational climate is descriptive of the total organization, and although measured, is gauged primarily by the perception of its members. In the educational setting, the organizational academic climate is the multidimensional social space conformed by a very complex net of social and psychological interactions among members of an academic community, where processes of educational institutions take place (Flories, Rodriguez and Franco, 2010). Research demonstrated that open and healthy educational institute's climate represents a vital role in the development of purposefully directed educational institute environment (Hoy and Feldman, 1987, 1999).

Hoy and Miskel (1996) assert that educational climate is a relatively enduring quality of the entire educational institute that is experienced by members, describes their collective perceptions of routine behavior, and affects their attitudes and behavior in the educational institute. Investigating the concept of organizational academic climate in educational institutes has proven to be challenging. A closer look at the relationship of the educational institute climate to student learning and performance is needed, especially in Arab countries, as few studies have concentrated on the effects of the educational climate on student performance. It is worth mentioning, that the connection between academic climate and student academic performance has been well-established in research (Kober, 2001; Smith, 2002; Loukas and Robinson, 2004; Norton, 2008).

On the other hand, self-efficacy has its root in the social cognitive theory proposed by Bandura (1986). Self-efficacy is concerned with a person's beliefs in his or her capabilities to learn or perform behavior at 
designated levels (Bandura, 1986, 1997). The burgeoning interest in self-efficacy could be attributed to the consistent claims by Bandura that judgments of capability a person brings to a specific task are strong predictors of the performance that results from that task and mediates the other determinants of that performance (Adeyemo, 2007).

Self-efficacy is a multidimensional construct that varies according to the domain of demands (Zimmerman, 2000), and therefore it must be evaluated at a level that is specific to the outcome domain (Bandura, 1986; Pajares, 1996). Thus in academic settings, one should measure academic self-efficacy rather than generalized self-efficacy, where the academic self-efficacy refers to personal judgments of one's capabilities to organize and execute courses of action to attain designated types of educational performances. A large meta-analysis of studies of self-efficacy in academic environments concluded that the most specific academic self-efficacy indices had the strongest effect on academic outcomes, while the more generalized measures were less closely associated (Zajacova, Lynch, and Espenshade, 2005).

Studies on perceived academic self-efficacy and student learning have confirmed that perceived self-efficacy impacts on students' aspirations, levels of interest in academic pursuit, academic accomplishments and how well they prepare themselves for different occupational careers (Bandura, 1995). A meta-analysis of 39 research works done by Multon, Brown, \& Lent (1991), Bandura and others (Bandura, 1989; Zimmerman, Bandura, and Martinez, 1992) confirmed the influence of academic self-efficacy on academic success and persistence.

Many previous studies examined the influence of academic climate and some individual variables, for example, academic self-efficacy in the educational institutes in order to determine what main factors may affect both students' performance and achievement level. Some of those studies concentrate on examining the relationship between academic climate and students academic performance (Smith, 2002; Hoy, Tarter and Hoy, 2006; Macneil, Prater and Busch, 2009), while other studies, have shown that academic self-efficacy is positively associated with grades in college (Chemers, Hu and Garcia, 2001; Greene, Miller, Crowson, Duke and Akey, 2004; Zajacova, Lynch, \& Espenshade, 2005; Sharm and Silbereisen, 2007; Akomolafe, Ogunmakin and Fasooto, 2013).

Some other studies have examined how individual variables such as, gender can influence student's perceptions of self-efficacy and academic performance. (Momanyi, Ogoma and Misigo, 2010) discovered that there was no significant difference between male and female in self-efficacy, but there was a significant difference between genders in academic performance. (Peters, 2013), however, indicated opposite findings, stating that males reported a higher level of mathematic self-efficacy than females, while no gender differences were found in measures of academic performance in mathematics.

Most of the studies on the relationship between academic climate, academic self-efficacy and academic performance reviewed were carried out in Europe and Asia. Few studies on these variables have been reported in Egypt. This is one of the gaps that this study intends to fill, as student perceptions of climate as well as self-efficacy may vary from country to country. Student perceptions may vary because of differing value structures governed by different cultures. Thus, the same study conducted in a new environment may contribute different results.

While many previous studies examined the direct relationships between all three variables, few studies investigated the interaction effect between those variables (e.g., Peters, 2013), the results of this study indicate that academic climate did not moderate the relationship between mathematics self-efficacy and academic performance. Another study (Canpolat, 2012) reported a mediating effect of self-efficacy in the relationship between academic climate and goal orientations. In this study, we aim to measure the role of academic self-efficacy as a mediator variable in the relationship between academic climate and academic performance.

This research has both theoretical and practical significance. The concepts of academic climate, academic self-efficacy and students' academic performance provide fertile ground for an important line of inquiry about the nature of effective educational institutes. This is also important for university administrators interested in building a positive academic climate and raising the quality of the learning process, which in turn will affect students' achievement and their academic performance.

That being said, Egyptian universities emphasize the complement of their educational mission while satisfying the students' needs. Because of their interest in quality education and competitiveness, they make every effort to ensure continuous improvements, not only in activities related to the services they offer, but in the academic climate in which the teaching and learning process takes place.

Because related previous studies, such as (Entwistle, 1987) have shown that students' perception of the academic 
climate has a strong influence on their learning quality and student performance, it becomes the main factor of study in our research. We examine the academic climate as perceived by students in some of Assiut university faculties in Egypt.

\section{Study Variables}

\subsection{Academic Climate}

Refers to, "a group of dimensions and characteristics that distinguish the academic work environment as perceived by students studying in this environment".

A number of previous studies, conducted in similar environments - Arab countries - (e.g., Elmalky, 1997; Elmahbob, 1998) concluded that some aspects and dimensions have a great influence in determining the nature of academic climate at the educational institutions. These aspects have been modified and can be summarized as follows:

Teachers: this dimension includes teaching skills, personal qualities, relationships with students and teacher knowledge.

Physical environment and available facilities: includes buildings, rooms, wings, physical structures, halls, laboratories, foyers, recreation areas, athletic facilities and residences.

Subjects: refers to the courses, the proportionality, coherence and substance of the courses contents with the time period of semesters.

Managerial environment: refers to the level(s) of sufficiency with regard to student services offered by staff. Includes, admissions, financial support availability, support for students with special needs and so on.

\subsection{Academic Self-Efficacy}

Refers to "personal judgments of one's capabilities to organize and execute courses of action to attain designated types of educational performances".

\subsection{Academic Performance}

Refers to, "the extent to which students have achieved their educational goals". A cumulative grade point average (GPA) will calculate as an indicator of overall academic performance. In previous studies, GPA was identified as a strong predictor of college students' academic performance (Feldman, 1993; Garton, Ball and Dyer, (2002).

\section{Research Questions}

The research questions central to this study are:

1) What is the effect of perceived academic climate on students' levels of academic performance?

2) What is the effect of students' levels of academic self-efficacy on students' levels of academic performance?

3) What is the effect of perceived academic climate on students' level of academic self-efficacy?

4) What is the mediating effect of perceived academic self-efficacy on the relationship between perceived academic climate and students' level of academic performance?

5) Do individual variables such as gender and faculty type, affect the mediating role of perceived academic self-efficacy on the relationship between perceived academic climate and the students' level of academic performance?

\section{Hypotheses of the Study}

The current study analyzes the following hypotheses:

1) "There is a significant positive relationship between perceived academic climate and the students' level of academic performance."

2) "There is a significant positive relationship between the perceived academic climate and the students' level of academic self-efficacy."

3) "There a significant positive relationship between the students' level of academic self-efficacy and the students' level of academic performance."

4) "Students' academic self-efficacy as a mediator has a positive effect in the relationship between the perceived academic climate and the students' level of academic performance." This hypothesis is subdivided into the following minor hypotheses:

a. "Students' academic self-efficacy as a mediator has a positive effect in the relationship between the perceived 
academic climate and the level of academic performance of students belonging to practical faculties."

b. "Students' academic self-efficacy as a mediator has a positive effect in the relationship between the perceived academic climate and the level of academic performance of students belonging to theoretical faculties."

c. "Students' academic self-efficacy as a mediator has a positive effect in the relationship between the perceived academic climate and the level of academic performance of male students."

d. "Students' academic self-efficacy as a mediator has a positive effect in the relationship between the perceived academic climate and the level of academic performance of female students."

Based on the above hypotheses, the following conceptual framework was developed:

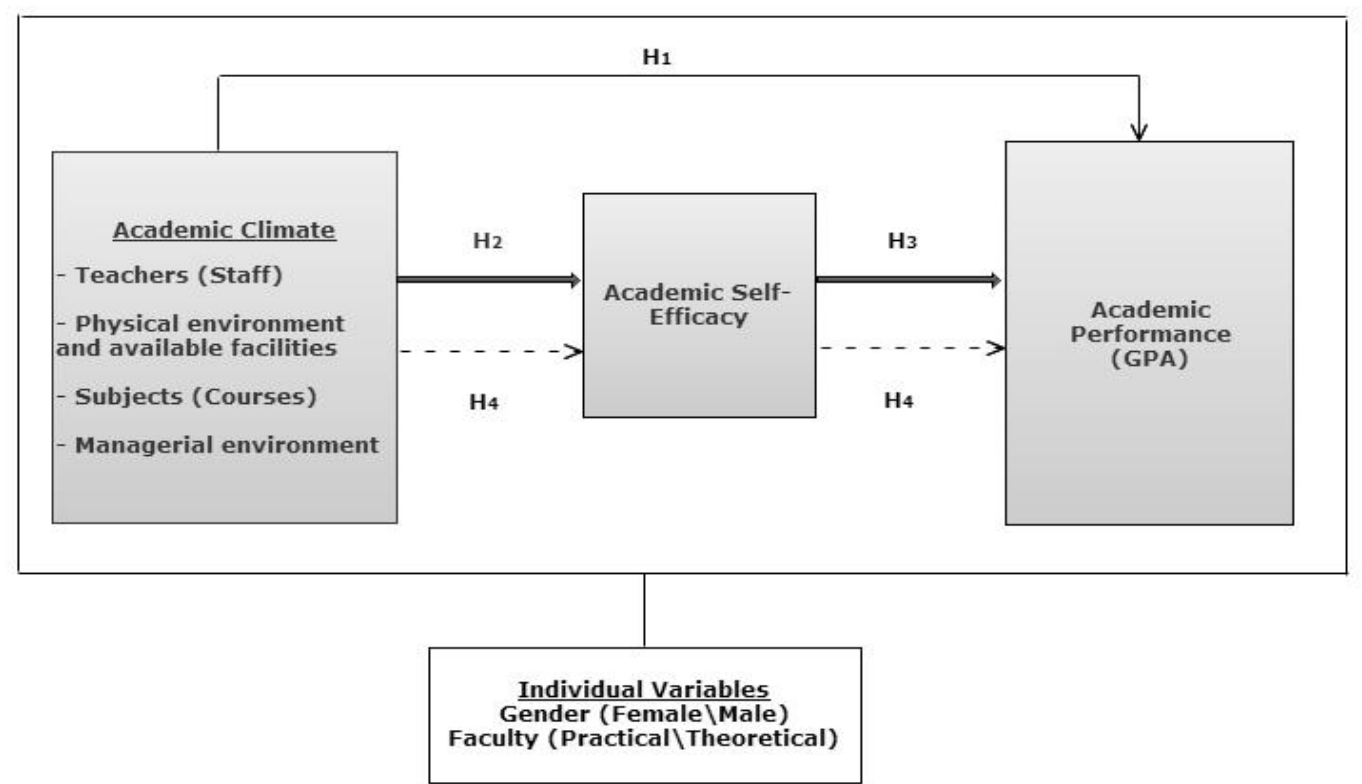

Figure 1. Conceptual model

This model contains three direct relations and one mediating relation. The first direct relation is between academic climate and academic performance (H1). The second relation is between academic climate and academic self-efficacy (H2), and the last direct relation between academic self-efficacy and academic performance $(\mathrm{H} 3)$. The mediating relation takes academic self-efficacy as a mediating variable on the relationship between it, and academic climate and performance (H4).

\section{Study Population}

This present study aims to examine the effect of perceived academic climate and perceived academic self-efficacy on students' level of academic performance at Assiut University in Egypt which includes different faculties with a large number of students.

Table 1. Total numbers of students enrolled at Assiut University Faculties for the academic year 2010/2011

\begin{tabular}{ccc}
\hline Faculty & Students & $* \%$ \\
\hline Medicine & 3316 & $4.7 \%$ \\
Veterinary Medicine & 1201 & $1.7 \%$ \\
Pharmacy & 3957 & $5.6 \%$ \\
Engineering & 5624 & $7.9 \%$ \\
Computer Science & 753 & $1.07 \%$ \\
\hline
\end{tabular}




\begin{tabular}{ccc}
\hline Science & 1994 & $2.8 \%$ \\
Agriculture & 608 & $0.86 \%$ \\
Nursing & 612 & $0.87 \%$ \\
Commerce & 10469 & $14.8 \%$ \\
Law & 19509 & $27.7 \%$ \\
Education & 4555 & $6.47 \%$ \\
Specific Education & 1113 & $1.58 \%$ \\
Education - ElWady ElGded & 1439 & $2.04 \%$ \\
Physical Education & 1922 & $2.73 \%$ \\
Social Work & 5528 & $7.85 \%$ \\
Arts & 6305 & $8.96 \%$ \\
\hline Total & 70340 & $100 \%$ \\
\hline
\end{tabular}

* This percentage reflects number of faculty students to the total number of university students.

Source. Office of students' affairs at Assiut University

Based on the table above there are two kinds of faculties at Assiut University. Practical faculties: Medicine, Veterinary Medicine, Pharmacy, Engineering Computer Science, Agriculture, Science and Nursing, and theoretical faculties: Commerce, Education, Arts, Physical Education, Law, Education El-Wady, Specific-Education and Social Work. The following faculties: Pharmacy, Engineering and Computer Science will be selected to represent the practical fields and the following faculties: Commerce, Law and Education El-Wady to represent the theoretical fields. These faculties were selected as they represented more than $60 \%$ of the total number of students either enrolled in practical or theoretical faculties. For the purposes of the current research the study population will include all enrolled students in the final year (Graduation Year) at the faculties mentioned above due to their ability to understand and perceive the academic climate in a logical and complete way.

Table 2. Numbers of enrolled students in the final year at the study population faculties

\begin{tabular}{cc}
\hline Faculty & Numbers of final year students \\
\hline Pharmacy & 673 \\
Engineering & 927 \\
Computer Science & 116 \\
Commerce & 2622 \\
Law & 5171 \\
Education El-Wady & 508 \\
\hline Total & 10017
\end{tabular}

Source. Office of student affairs at Assiut University.

\section{Sample Description}

For the purposes of this study, sampling was adopted instead of surveying the whole population due to the high volume of the student population. We have relied on a Stratified Random Sample to ensure that all parts of the population (practical and theoretical faculties) are represented in the sample in order to increase the efficiency and decrease the error in the estimation. Statistical tables have been used to determine sample size. A $95 \%$ confidence interval is desired. The appropriate sample size is 370 . To allow for possibilities of non-respondents, we have increased this sample size from 370 to 400.200 questionnaires were distributed to students enrolled in the practical fields and same number for theoretical faculty students. 
Table 3. Distribution of the study sample

\begin{tabular}{lccccccccc}
\hline $\begin{array}{l}\text { Practical } \\
\text { faculties }\end{array}$ & $\%$ & $\begin{array}{l}\text { Sample } \\
\text { students } \\
\text { number }\end{array}$ & \multicolumn{2}{c}{$\begin{array}{c}\text { Response } \\
\text { Number }\end{array}$} & $\begin{array}{l}\text { Theoretical } \\
\text { percentage }\end{array}$ & faculties & $\begin{array}{l}\text { Sample } \\
\text { students } \\
\text { number }\end{array}$ & \multicolumn{3}{c}{ Response } \\
Number & percentage \\
\hline Pharmacy & 39 & 78 & 55 & 70.5 & Commerce & 32 & 64 & 51 & 79.5 \\
Engineering & 54 & 108 & 64 & 60 & Law & 62 & 124 & 71 & 57 \\
$\begin{array}{l}\text { Computer } \\
\text { Science }\end{array}$ & 7 & 14 & 10 & 71.5 & $\begin{array}{c}\text { Education- } \\
\text { El Wady }\end{array}$ & 6 & 12 & 8 & 66.5 \\
Total & 100 & 200 & 129 & 65 & Total & 100 & 200 & 143 & 71.5 \\
\hline
\end{tabular}

Table 3. expresses that the response rate in the study sample is $65 \%$ for practical faculties and 71.5 for theoretical faculties. The following table indicates sample characteristics.

Table 4. Sample characteristics

\begin{tabular}{ccc}
\hline Individual Variables & Students Number & $\begin{array}{c}\text { Percentage of the total sample } \\
\text { size }\end{array}$ \\
\hline Gender & 191 & $70.2 \%$ \\
Male & 81 & $29.8 \%$ \\
Female & & \\
Faculty & 129 & $47.4 \%$ \\
Practical & 143 & $52.6 \%$ \\
Theoretical & & \\
\hline
\end{tabular}

\section{Measures and Data Analysis}

A questionnaire was designed for collecting data. This questionnaire included a group of designated scales for measuring the study variables and was divided into three parts. The first part was used to measure the independent variable (Academic Climate). We developed a 20-item questionnaire in Likert's scale, with five given values -1 . Totally agree, 2 . Agree, 3 . Not sure, 4 . Disagree, 5 . Totally disagree - that measures how students' perceived academic climate with regard to the determined dimensions: staff performance, physical environment and available facilities, subjects, and managerial environment. The second part was used to measure the mediating variable (students' level of academic self-efficacy) and is taken from (Landry, 2003). The third part of the questionnaire was used for obtaining personal data about the students included in the survey. This section asks the participants to record their faculty \& gender. Respondents also reported their name or university ID number, which we used a month later to access students' academic records (GPA). Permission was obtained from the students' affairs office at Assiut University. It is worth mentioning that 70 questionnaires were distributed to a random sample of students prior to the actual study in order to test the Academic Climate section of the questionnaire's reliability and validity. The table below indicates validity and reliability coefficients by using Crombach's alpha test. The co-efficient of internal consistency by Crombach's alpha of the scale $(\alpha)=0.70$. The test-retest reliability coefficient obtained was 0.81 .

Data collected was analyzed using both descriptive and inferential statistics. The descriptive statistics used were means and percentages, whereas, the inferential statistics used were t-test for individual variables and Pearson product moment correlation. Both simple regression analysis and stepwise multiple regression analysis were used to examine the study hypotheses. 


\section{Results}

Table 5. Means, Standard deviations and Correlations between study variables

\begin{tabular}{lccclll}
\hline & $\mathrm{N}$ & $\mathrm{M}$ & $\mathrm{SD}$ & $\begin{array}{l}\text { Academic } \\
\text { climate } \\
\text { (total) }\end{array}$ & $\begin{array}{l}\text { Academic } \\
\text { Self-efficacy }\end{array}$ & $\begin{array}{l}\text { Academic } \\
\text { Performance }\end{array}$ \\
\hline $\begin{array}{l}\text { Academic } \\
\text { climate (total) }\end{array}$ & 272 & 3.49 & 0.546 & - & $0.278^{*}$ & $0.404^{*}$ \\
$\begin{array}{l}\text { Academic } \\
\text { Self-efficacy }\end{array}$ & 272 & 3.33 & 0.774 & & & $0.586^{*}$ \\
$\begin{array}{l}\text { Academic } \\
\text { Performance }\end{array}$ & 272 & 70.35 & 0.915 & & & \\
\hline
\end{tabular}

* Correlation is significant at the 0.05 level (2-tailed)

Mean from 1 to 100 (Independent variable)

$\mathrm{N}$ refers to study sample

The previous table shows the correlations between the variables. As demonstrated in the table, the mean scores for academic climate, academic self-efficacy and academic performance are 3.49, 3.33 and 70.35. The corresponding standard deviation for the three variables is: $0.546,0.774$ and 9.15 . Significant relationships were found between the study variables: academic climate and academic self-efficacy $(r=0.278, p<0.05)$; academic climate and academic performance $(r=0.404, \mathrm{p}<0.05)$; academic self-efficacy and academic performance $(\mathrm{r}=$ $0.586, \mathrm{p}<0.05)$.

Table 6. T-test results of study individual variables

\begin{tabular}{|c|c|c|c|c|c|c|}
\hline & Indivi & variables & Mean & t-value & Significance & Significance \\
\hline \multirow{4}{*}{$\begin{array}{l}\text { Perceived } \\
\text { academic } \\
\text { climate }\end{array}$} & \multirow[t]{2}{*}{ Gender } & Female & 3.505 & 0.295 & 0.796 & \multirow{2}{*}{$\begin{array}{c}\text { Not } \\
\text { significant }\end{array}$} \\
\hline & & Male & 3.485 & & & \\
\hline & \multirow[t]{2}{*}{ Faculty } & Practical & 3.570 & 2.330 & 0.021 & \multirow{2}{*}{ Significant } \\
\hline & & Theoretical & 3.413 & & & \\
\hline \multirow{4}{*}{$\begin{array}{l}\text { Academic } \\
\text { self-efficacy }\end{array}$} & \multirow[t]{2}{*}{ Gender } & Female & 3.331 & -0.027 & 0.978 & \multirow{2}{*}{$\begin{array}{c}\text { Not } \\
\text { significant }\end{array}$} \\
\hline & & Male & 3.334 & & & \\
\hline & \multirow[t]{2}{*}{ Faculty } & Practical & 3.292 & 0.856 & 0.395 & \multirow{2}{*}{$\begin{array}{l}\text { Not } \\
\text { significant }\end{array}$} \\
\hline & & Theoretical & 3.374 & & & \\
\hline \multirow{4}{*}{$\begin{array}{l}\text { Academic } \\
\text { performance }\end{array}$} & \multirow{2}{*}{ Gender } & Female & 68.747 & 0.295 & 0.069 & \multirow{2}{*}{$\begin{array}{c}\text { Not } \\
\text { significant }\end{array}$} \\
\hline & & Male & 71.034 & & & \\
\hline & \multirow{2}{*}{ Faculty } & Practical & 70.172 & 2.330 & 0.710 & \multirow{2}{*}{$\begin{array}{l}\text { Not } \\
\text { significant }\end{array}$} \\
\hline & & Theoretical & 69.158 & & & \\
\hline
\end{tabular}

T-test results indicate that the only significant differences were within the students' perception of academic climate. For all other variables, neither gender nor faculty produced measurable differences. 
Table 7. Sample Regression Analysis showing the influence of Perceived Academic Climate on Academic Performance

\begin{tabular}{cccccc}
\hline $\begin{array}{c}\text { Independent } \\
\text { variable }\end{array}$ & $\mathbf{R}^{2}$ & $\overline{\mathbf{R}}^{2}$ & $\mathrm{~F}$ & Beta & $\begin{array}{c}\text { Significance } \\
\text { Level }\end{array}$ \\
\hline $\begin{array}{c}\text { Academic } \\
\text { Climate }\end{array}$ & 0.163 & 0.160 & 50.088 & 0.404 & $0.00^{* *}$ \\
\hline $\mathrm{P}<0.01^{* *}$ & & & & & \\
\hline
\end{tabular}

Table 7 indicates the results of sample regression analysis. The results demonstrate that perceived academic climate was found to impact significantly and positively $(\beta=0.404, \mathrm{p}<0.01)$ on students' level of academic performance, as perceived academic climate explains $16 \%$ of the variation in students' level of academic performance (GPA).

Table 8. Sample Regression Analysis Showing the Influence of Perceived Academic Climate on Academic Self-Efficacy

\begin{tabular}{cccccc}
\hline $\begin{array}{c}\text { Independent } \\
\text { variable }\end{array}$ & $\mathbf{R}^{2}$ & $\overline{\mathbf{R}}^{2}$ & $\mathrm{~F}$ & Beta & $\begin{array}{c}\text { Significance } \\
\text { Level }\end{array}$ \\
\hline $\begin{array}{c}\text { Academic } \\
\text { Climate }\end{array}$ & 0.077 & 0.074 & 21.555 & 0.278 & $0.000^{* *}$ \\
\hline $0.05^{* *}$ & & & & & \\
\hline
\end{tabular}

Previous table results demonstrate that perceived academic climate was found to impact significantly and positively $(\beta=0.278, p<0.05)$ on academic self-efficacy, as perceived academic climate explains $7.4 \%$ of the variance in the perceived academic self-efficacy.

Table 9. Sample Regression Analysis Showing the Influence of Perceived Academic Self-Efficacy on Academic Performance

\begin{tabular}{cccccc}
\hline $\begin{array}{c}\text { Independent } \\
\text { variable }\end{array}$ & $\mathbf{R}^{2}$ & $\overline{\mathbf{R}}^{2}$ & $\mathrm{~F}$ & Beta & $\begin{array}{c}\text { Significance } \\
\text { Level }\end{array}$ \\
\hline $\begin{array}{c}\text { Academic } \\
\text { Climate }\end{array}$ & 0.344 & 0.341 & 135.276 & 0.586 & $0.000^{* *}$ \\
\hline $0.05^{* *}$ & & & & & \\
\hline
\end{tabular}

The results indicate that perceived academic self-efficacy is found to impact significantly and positively ( $\beta=$ $0.586, \mathrm{p}<0.05)$ on academic performance, as perceived academic climate explains $34 \%$ of the variance in academic performance (GPA). Baron \& Kenny (1986), laid out several requirements that must be met to form a true mediation relationship. They are outlined below:

Regress the dependent variable on the independent variable. In other words, confirm that the independent variable is a significant predictor of the dependent variable.

Regress the mediator on the independent variable. In other words, confirm that the independent variable is a significant predictor of the mediator.

Regress the dependent variable on both the mediator and independent variable. In other words, confirm that the mediator is a significant predictor of the dependent variable, while controlling for the independent variable. 
Table 10. Multiple Regression Analysis showing the mediating influence of academic self-efficacy on the relationship between perceived academic climate and academic performance

\begin{tabular}{|c|c|c|c|c|c|c|}
\hline Stage No. & $\begin{array}{c}\text { Input } \\
\text { Variables }\end{array}$ & $\mathbf{R}^{2}$ & $\Delta \mathrm{R}^{2}$ & $\mathrm{~F}$ & Beta & $\begin{array}{c}\text { Significance } \\
\text { Level }\end{array}$ \\
\hline 1 & $\begin{array}{l}\text { Academic } \\
\text { self-efficacy }\end{array}$ & 0.343 & 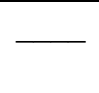 & 134.317 & 0.513 & $0.000^{* *}$ \\
\hline 2 & $\begin{array}{l}\text { Academic } \\
\text { climate }\end{array}$ & 0.406 & 0.063 & 87.538 & 0.261 & $0.000^{* *}$ \\
\hline
\end{tabular}

$\mathrm{P}<0.05^{* *}$

Table 11. (R2) values before and after entering the mediator variable on the relationship between academic climate and academic performance

\begin{tabular}{cccc}
\hline Independent Variable & $\mathbf{R}^{2}$ before & $\mathbf{R}^{2}$ After & Change in $\mathbf{R}^{2}$ \\
\hline Academic Climate & 0.160 & 0.063 & $0.097-$ \\
\hline
\end{tabular}

Tables 10 and 11. indicate the results of multiple regression analysis. The results demonstrate that influence of perceived academic climate on academic performance decreased (from 0.160 to 0.063 ). In other words, before entering the mediator variable (academic self-efficacy) perceived academic climate explains $34 \%$ of the variance in academic performance. This percentage decreased to $6.3 \%$ after entering academic self-efficacy as a mediator variable on the relationship between perceived academic climate and academic performance. Thus, we accepted the following hypotheses:

"Students' academic self-efficacy as a mediator has a positive effect in the relationship between the perceived academic climate and the students' level of academic performance."

Table 12. (R2) Values before and after entering the mediator variable on relationship between academic climate and academic performance of practical and theoretical students, male and female students separately

\begin{tabular}{cccc}
\hline $\begin{array}{c}\text { Independent variable } \\
\text { Academic climate }\end{array}$ & $\mathbf{R}^{2}$ before & $\mathbf{R}^{2}$ After & Change in $\mathbf{R}^{2}$ \\
\hline Practical faculties sample & 0.343 & 0.343 & -0.075 \\
Theoretical faculties sample & 0.075 & $*$ zero & -0.034 \\
Male students sample & 0.066 & 0.032 & -0.117 \\
Female students sample & 0.194 & 0.077 &
\end{tabular}

*Full Mediation. As perceived academic climate is no longer significant when academic self-efficacy is controlled.

Table 12 indicates that academic self-efficacy mediated the relationship between perceived academic climate and academic performance of theoretical faculties sample (full mediation), and male and female samples (partial mediation). In contrast it could not mediate this relationship in practical faculties sample as (R2) value has not changed after entering academic self-efficacy as a mediator variable.

\section{Discussion}

The results found in this study have confirmed that perceived academic climate is a critical factor influencing academic performance and achievement. This has again strengthened previous findings concerning academic climate as a vital factor affecting academic performance (e.g., Peng and Wright, 1994; Pimparyon, Caleer, Pemba and Roff, 2000; Maslawski, 2001; Hoy et al. 1990, 2006).

It should be noted that the linkage between academic climate and academic performance was found to be mediated by academic self-efficacy. The effect of academic self-efficacy on academic performance and achievement is well documented in literature (Brown, Lent, and Larkin, 1989; Zajacova, et al., 2005; Sharm and 
Silbereisen, 2007; Akomolafe, et al., 2013). The relationship between academic self-efficacy and academic performance can be understood from the perspective that students with high sense of efficacy have the capacity to accept more challenging tasks, high ability to organize their time, increased persistence in the face of obstacles, show lower anxiety levels, show flexibility in the use of learning strategies and have a high ability to adapt with different educational environments.

According to the current study results, Academic Self-efficacy differs in their impacts on students' academic performance depending on faculties' nature (practical/theoretical), which has not been mentioned in the previous studies. In other words, academic self-efficacy influences academic performance of theoretical faculties' students more than those enrolled in practical faculties.

Multiple regression analysis shows that academic self-efficacy has a strong positive effect (statistical analysis showed full mediation case) in the relationship between perceived academic climate and academic performance of students enrolled in theoretical faculties. We may attribute this to the nature of studying in these faculties which depends largely on lectures and reading some scientific references which in turn relate to some individual aspects as self-efficacy.

In contrast, results indicate that academic self-efficacy could not mediate the relationship between academic climate and academic performance of students enrolled in practical faculties which can be understood from the perspective that practical faculties' students are largely influenced by physical environment and the available facilities (e.g., Laboratories, Workshops, Samples and Networks). Accordingly, lack of these facilities badly affects the educational process which in turn reflects negatively on students' performance, whatever the students' level of academic self-efficacy.

\section{Implications and Recommendation}

The findings of the present study have important implications for improving both the educational process quality and its outputs. University administrators should realize that students' academic performance and achievement are affected by several situational and individual factors, of which academic climate and academic self-efficacy are critical components.

Results demonstrated that perceived academic climate has a significant affect on students' academic performance. Administrators, therefore, would benefit from obtaining student opinions on this matter to ensure their institutions are better able to provide them with an appropriate environment tailored to students' needs.

Administration should give attention to improve areas of the learning environment. Some suggestions are as follows:

1) Ensuring teachers have a wide knowledge base within their field and that they can effectively pass that knowledge on to students.

2) Maintaining physical structures and updating equipment to provide the highest possible level of productivity.

3) Keeping course material proportionate to the length of the subject term and ensuring all material is coherent and contains substance.

4) Ensuring that there is a high level of support for students, including student services, such as, financial support and availability.

Moreover, conscious efforts should be made to raise the students' level of academic self efficacy, particularly for student's enrolled in theoretical faculties. Students' academic performance can also be enhanced by exposing them to academic self-efficacy intervention programs. This can be accomplished by counseling and having educational psychologists working in the university setting.

This study sought to add a modest contribution to a growing body of educational institute's literature. This study also emphasized the important role that academic self-efficacy - as one of the individual variables - plays on the relationship between academic climate and students' academic performance. It is a beginning not an end. There are many other research questions that need to be addressed, namely which of the four dimensions (teachers, physical environment, subjects, and managerial environment) has the greatest effect on student performance? Is the relationship between academic climate and students' performance mediated by other individual variables such as self-esteem? Do all academic climate dimensions have the same influence on students' academic performance? If yes, does the personality type play a mediator role between these climate dimensions and students' performance? There are a host of research questions that can be addressed under the concept of academic climate in the educational process.

This study is limited in that the student sample size was relatively small. Since student performance was 
measured by GPA, students who participated in the study were required to identify themselves by name. Some were not willing to do this, and this caused there to be a number of non-respondents in each group. This study examined only four dimensions within academic climate, as these dimensions play a vital role in the education system of Egypt. Other dimensions, which were not covered within this study include: exam structure and teaching approaches. This research relied on a questionnaire as a measurement tool. There is some debate on whether questionnaires can be depended on as effective measures in the field of organizational behavior.

\section{References}

Adeyemo, D. A. (2007). Moderating influence of emotional intelligence on the link between academic self-efficacy and achievement of University students. Psychology Developing Societies, 19(2), 199-213. http://dx.doi.org/10.1177/097133360701900204

Akomolafe, M. J., Ogunmakin, A. O., \& Fasoota, G. M. (2013). The role of academic self-efficacy, academic motivation and academic self-concept in predicting secondary school students' academic performance. Journal of Educational and Social Research, 3(2), 335-342.

Bandura, A. (1986). Social foundation of thought and action: A social cognitive theory. Upper Saddle River, New Jersey: Prentice Hall.

Bandura, A. (1994). Self-Efficacy. Encyclopedia of Human Behavior, 4, 71-81.

Bandura, A. (1995). Exercise of personal and collective efficacy. In A. Bandura (Ed.), Self-efficacy in Changing Societies (pp. 1-45). New York: Cambridge University Press. http://dx.doi.org/10.1017/CBO9780511527692.003

Bandura, A. (1997). Self-efficacy: The exercise of control. New York: Freeman. Retrieved from http://books.google.ca/books?id=JbJnOAoLMNEC\&printsec=frontcover

Brown, S. D., Lent, R. D., \& Larkin, K. C. (1989). Self-efficacy as moderator of scholastic aptitude-academic $\begin{array}{lllll}\text { performance relationship. Journal of Vocational Behavior, 35, 64-75. } & \text {. }\end{array}$ http://dx.doi.org/10.1016/0001-8791(89)90048-1

Canpolat, A. M. (2012). The mediating role of self-efficacy in the relationship between class climate and goal orientations in physical education. World Applied Sciences Journal, 16(1), 76-85. http://idosi.org/wasj/wasj16(1)12/12.pdf

Chemers, M. M., Hu, L., \& Garcia, B. F. (2001). Academic self-efficacy and first-year college student performance and adjustment. Journal of Educational Psychology, 93(1), 55-64. http://dx.doi.org/10.1037/0022-0663.93.1.55

Edmonds, E. (1979). Effective schools for the urban poor. Educational Leadership, 37, 15-24.

Elmahbob, A. I. (1998). Students perception of academic climate in the college of Education. Association of Arab Universities, 32, 45-74.

Elmalky, F. B. (1997). Student satisfaction of the educational services and the administrative work elements. Journal of Economy and Trade, 2, 1-44.

Entwistle, N. J. (1987). A model of the teaching-learning process. Research in Education and Cognitive Psychology (pp. 13-28). London: S.R.H.E/ Open University Press.

Feldman, M. J. (1993). Factors associated with one-year retention in a community college. Research in Higher Education, 34(4), 503-512. http://dx.doi.org/10.1007/BF00991857

Flores, P. A., Rodriguez, J. A., \& Franco, J. S. (2010). Students' academic climate perception of the school of business of a Mexican university. American Journal of Business Education, 3(7), 11-16. Retrieved from http://journals.cluteonline.com/index.php/AJBE/article/view/454

Garton, B. L., Ball, A. L., \& Dyer, J. E. (2002). The academic performance and retention of college of agriculture students. Journal of Agricultural Education, 43(1), 45-56. http://dx.doi.org/10.5032/jae.2002.01046

Greene, B. A., Miller, R. B., Crowson, M., Duke, B. L., \& Akey, K. L. (2004). Predicting high school students' cognitive engagement and achievement: Contributions of classroom perceptions and motivation. Contemporary Educational Psychology, 29, 362-482. http://dx.doi.org/10.1016/j.cedpsych.2004.01.006

Hoy, W. K. (1990). Organizational climate and culture: A conceptual analysis of the school work place. Journal of Educational and Psychological Consultation, 1(2), 149-168. 
http://dx.doi.org/10.1207/s1532768xjepc0102_4

Hoy, W. K., \& Feldman, J. A. (1987). Organizational health: The concept and its measure. Journal of Research and Development in Education, 20, 30-47.

Hoy, W. K., Tarter, C. J., \& Kottkamp, R. B. (1991). Open schools healthy schools: Measuring organizational climate. Sage, Newbury Park, CA. Retrieved from $\mathrm{http}: / /$ www.amazon.com/Open-SchoolsHealthy-Measuring-Organizational/dp/0803937849

Hoy, W. K., \& Miskel, C. G. (1996). Educational administration: Theory, research, and practice (5th ed.). McGraw-Hill, $\quad$ New $\quad$ York, NY Netrieved http://books.google.ca/books?id=FJ39pR4G-B8C\&printsec=frontcover

Hoy, W. K., \& Sabo, D. J. (1998). Quality middle school: Open and healthy. Corwin Press, inc., Thousand Oaks, CA.

Hoy, W. K., \& Feldman, J. (1999). Organizational health profiles for high schools. In Frieiberg, J. (Ed.), School Climate: Measuring. Sustaining, and Improving. Falmer Press, London.

Hoy, W., Tarter, C., \& Hoy, A. (2006). Academic optimism of schools: a force for student achievement. American Educational Research Journal, 43(3), 425-446. http://dx.doi.org/10.3102/00028312043003425

Kober, N. (2001). It takes more than testing: Closing the achievement gap. A report of the center on education policy. Washington D. C.

Lane, J., \& Lane, A. M. (2001). Self-efficacy and academic performance. Social Behavior and Personality, 29, 687-694. http://dx.doi.org/10.2224/sbp.2001.29.7.687

Landry, C. C. (2003). Self-efficacy, motivation and outcomes expectation correlates of college students' intention certainty. $\mathrm{Ph}$ D. Thesis. University of Louisiana. Retrieved from http://etd.lsu.edu/docs/available/etd-0409103-084327/

Loukas, A., \& Robinson, S. (2004). Examining the moderating role of perceived school climate in early adolescent adjustment. Journal of Research on Adolescents, 14(2), 53-67. http://dx.doi.org/10.1111/j.1532-7795.2004.01402004.x

Macneil, A. J., Prater, D. L., \& Busch, S. (2009). The effect of school culture and climate on student achievement. International Journal of Leadership in Education, 12(1), 73-84. http://dx.doi.org/10.1080/13603120701576241

Maslowski, R. (2001). School culture and school performance: An explorative study into the organizational culture of secondary schools and their effects. Endschede, The Netherlands: Twente University Press. Retrieved from http://doc.utwente.n1/36122/

Momanyi, J. M., Ogoma, S. O., \& Misigo, B. L (2010). Gender differences in self-efficacy and academic performance in science subjects among secondary school students in Lugari District. Kenya. Educ. j. behav. Sci, 1(1), 62-77.

Multon, L. W., Brown, S. D., \& Lent, R. W. (1991). Relation of self-efficacy beliefs to academic outcomes: A meta-analytic investigation. Journal of Counseling Psychology, 38, 30-38. http://dx.doi.org/10.1037/0022-0167.38.1.30

Norton, M. S. (2008). Human resources administration for educational leaders. New York: Sage. Retrieved from http://www.sagepub.com/books/Book231824

Pajares, F. (1996). Self-efficacy beliefs in academic settings. Review of Educational Research, 66(4), 543-578. http://dx.doi.org/10.3102/00346543066004543

Peng, S., \& Wright, D. (1994). Explanation of academic achievement of Asian American students. Journal of Educational Research, 87(6), 346-369. http://dx.doi.org/10.1080/00220671.1994.9941265

Peters, M. L. (2013). Examining the relationships among classroom climate, self-efficacy, and achievement in undergraduate mathematics: A multi-level analysis. International Journal of Science and Mathematics Education, 11(2), 459-480. http://dx.doi.org/10.1007/s10763-012-9347-y

Pimparyon, P., Caleer, S. M., Pemba, S., \& Roff, S. (2000). Educational environment, student approaches to learning and academic achievement in a Thai nursing school. Medical Teacher, 22(4), 359-364. http://dx.doi.org/10.1080/014215900409456

Sharm, D., \& Silbereisen, R. K. (2007). Revisiting an era in Germany from the perspective of adolescents in 
mother-headed single-parent families. International Journal of Psychology, 42(1), 46-58. http://dx.doi.org/10.1080/00207590600663299

Smith, A. (2002). The organizational health of high schools and student proficiency in mathematics. The $\begin{array}{lllll}\text { International Journal of Educational Management, } & 16(2), & \text { 98-104. }\end{array}$ http://dx.doi.org/10.1108/09513540210418421

Zajacova, A., Lynch, S. M., \& Espenshade, T. J. (2005). Self-efficacy, stress, and academic success in college. Research in Higher Education, 46(6), 677-706. http://dx.doi.org/10.1007/s11162-004-4139-z

Zimmerman, B. J. (2000). Self-efficacy: An essential motive to learn. Contemporary Educational-Psychology, 25(1), 82-91. http://dx.doi.org/10.1006/ceps.1999.1016

Zimmerman, B. J., Bandura, A., \& Martinez-Pons, M. (1992). Self-motivation for academic attainment: The role of self-efficacy beliefs and personal goal-setting. American Educational Research Journal, 29, 663-676. http://dx.doi.org/10.3102/00028312029003663

\section{Copyrights}

Copyright for this article is retained by the author(s), with first publication rights granted to the journal.

This is an open-access article distributed under the terms and conditions of the Creative Commons Attribution license (http://creativecommons.org/licenses/by/3.0/). 